\title{
Chemical Composition and Antioxidant Activity of Bryophyllum pinnatum Root
}

\section{Orisakeye $\mathrm{OT}^{1^{*}}$, Oladoye $\mathrm{SO}^{2}$ and Peters $\mathrm{OA}^{1}$}

${ }^{1}$ Department of Chemistry, Afe Babalola University Ado-Ekiti, Nigeria

${ }^{2}$ Department of Chemistry, Ladoke Akintola University of Technology, Ogbomoso, Oyo state, Nigeria

\begin{abstract}
Bryophyllum pinnatum roots were air-dried and extracted using ethanol. The purpose of this study was to determine the presence of amino acids and peptide using ninhydrin and also to evaluate the antioxidant activity of the root of Bryophyllum pinnatum using DPPH. GC-MS analysis also revealed some of the constituents present in the root of Bryophyllum pinnatum.
\end{abstract}

Keywords: Bryophyllum pinnatum; Antioxidant activity; DPPH; GC-MS

\section{Introduction}

Bryophyllum pinnatum (Lam.) Synonym Kalanchoe pinnata (Lam.) is a perennial herb growing widely and used in folkloric medicine in tropical Africa, India, China, Australia and tropical America [1-4]. Classified as a weed, the plant flourishes throughout the Southern part of Nigeria. A number of active compounds, including flavonoids, glycosides, steroids, bufadienolides and organic acids, have been identified in Bryophyllum pinnatum [3]. Its bufadienolides are structurally similar to Cardiac glycosides and have demonstrated in clinical research to possess antimicrobial, antifungal, anticancer, anti tumour, insecticidal actions. It also possess other activities like anti-ulcer, anti-inflammatory and analgesic, antihypertensive, hepatoprotective, Nephroprotective, diuretic, antidiabetic, anticonvulsion, antioxidant, uterine relaxant, muscle relaxant and neurosedative activity and tocolysis activity [5,6]. Bryophyllum pinnatum is used in ethno medicine for treatment of earache, burns, abscesses, ulcer, insect bites, diarrhea and Lithiasis [1]. In South Eastern Nigeria, this herb is used to facilitate the dropping of the placenta of a newly born baby [1]. In traditional medicine, its stem, leaves and the whole plant have been extensively worked on while there is limited work done on the root of Bryophyllum pinnatum. The present work focus on the root of Bryophyllum pinnatum to test for amino acids and peptides, evaluate its antioxidant property and determine chemical constituents that could be present in the root.

\section{Materials and Methods}

Bryophyllum pinnatum (Lam) were collected in the month of April (2014) at Erifun village besides Afe Babalola University, AdoEkiti. Identification was done in the department of Botany, Ekiti State University, Ado-Ekiti.

\section{Preparation of plant extracts}

The collected roots were dried at room temperature for about two months. The dried roots were pulverized by a mechanical grinder. Extraction was done using ethanol. It was filtered and the filtrate was concentrated to dryness in vacuo to obtain the crude ethanol extract.

\section{Isolation}

Crude ethanol extract $(20 \mathrm{~g})$ was dissolved in 5\% ethanol and subjected to column chromatography. Elution was done using hexane, ethylacetate (95:5) $\mathrm{ml}$ in gradient. The elute in each test tube was tested on TLC. Tube fractions with similar TLC characteristics were pooled together and further subjected to column chromatography to obtain a pure spot (BPR001) on TLC plate. BPR 001 was a darkish green substance with r.f 0.65 . It had an antioxidant activity. It was showing as a deep pink reacting substance on silica with vanillin sulphuric acid.

\section{Antioxidant assay}

DPPH scavenging method: The test samples $(2 \mathrm{ml}$ extract solution in ethanol) were mixed with $4 \mathrm{ml}$ solution of DPPH in methanol) and different concentrations $(0.2-1 \mathrm{mg} / \mathrm{ml})$ were prepared. After $30 \mathrm{~min}$ at room temperature, the absorbance values were measured at $517 \mathrm{~nm}$ and converted into percentage of antioxidant activity. Ascorbic acid was used as a standard. Each assay was repeated thrice and recorded as mean of the triplicate.

$\%$ Scavenging Effect=[1-Abs. (s)/Abs. $(\mathrm{c})] \times 100$

Where, Abs. (s)=Absorbance of Sample, Abs. (c)=Absorbance of Control.

\section{Test for amino acids}

$0.2 \mathrm{~g}$ of ninhydrin was dissolved in $100 \mathrm{ml}$ of ethanol. The solution served as a spraying reagent on thin layer chromatography plate. 2 $\mathrm{ml}$ of hexane was used to dissolve the crude extract of Bryophyllum pinnata root and was spotted on thin layer chromatography plate. After spraying, the plate was now incubated in the oven until spots appear.

\section{Test for peptides}

$1 \%$ ninhydrin was dissolved in $17 \mathrm{ml}$ of glacial acetic acid and 83 $\mathrm{ml}$ of pyridine. The solution served as a spraying reagent on thin layer chromatography plate. $2 \mathrm{ml}$ of hexane was used to dissolve the crude extract of Bryophyllum pinnata root and was spotted on thin layer chromatography plate. After spraying, the plate was now incubated in the oven for $100^{\circ} \mathrm{C}$ for 5 minutes.

\section{GC-MS analysis of BPR 001}

The GC-MS analysis of Bryophyllum pinnata root extract was performed using a Clarus 500 Perkin Elmer gas chromatography

*Corresponding author: Orisakeye OT, Department of Chemistry, Afe Babalola University, Ado-Ekiti, Nigeria, Tel: +234 8037400826; E-mail: jumokeye@gmail.com

Received February 12, 2015; Accepted April 02, 2015; Published April 04, 2015

Citation: Orisakeye OT, Oladoye SO, Peters OA (2015) Chemical Composition and Antioxidant Activity of Bryophyllum pinnatum Root. Nat Prod Chem Res 3: 173. doi:10.4172/2329-6836.1000173

Copyright: (c) 2015 Orisakeye OT et al. This is an open-access article distributed under the terms of the Creative Commons Attribution License, which permits unrestricted use, distribution, and reproduction in any medium, provided the original author and source are credited. 
equipped with a Elite-5 capillary column (5\% phenyl $95 \%$ dimethylpolysiloxane) $(30 \mathrm{~nm} \times 0.25 \mathrm{~mm}$ ID $\times 0.25 \mu \mathrm{mdf})$ and mass detector turbomass gold of the company which was operated in EI mode. Helium was the carriers gas at a flow rate of $1 \mathrm{ml} / \mathrm{min}$. and the injector was operated at $290^{\circ} \mathrm{C}$ and the oven temperature was programmed as follows; $50^{\circ} \mathrm{C}$ at $8^{\circ} \mathrm{C} / \mathrm{min}$ to $200^{\circ} \mathrm{C}(5 \mathrm{~min})$ at $7^{\circ} \mathrm{C} / \mathrm{min}$ to $290^{\circ} \mathrm{C}(10 \mathrm{~min})$.

\section{Identification of components}

Interpretation on mass spectrum of GC-MS was done using the database of National Institute Standard and Technology (NIST), WILEY8, FAME having more than 62,000 patterns. The mass spectrum of the unknown component was compared with the spectrum of the known components stored in the (NIST), WILEY8, FAME library. The name, molecular weight and structure of the components of the test materials were ascertained.

\section{Result and Discussion}

\section{DPPH}

The DPPH test intends to measure the hydrogen atom or electron donor capacity of the extracts to the stable radical DPPH formed in solution [7]. The activity was expressed as the concentration of sample necessary to give a $50 \%$ reduction in the sample absorbance $\left(\mathrm{IC}_{50}\right)$. Extract exhibited considerable DPPH free radical scavenging activity as indicated by their $\mathrm{IC}_{50}$ values of $2.35 \mathrm{mg} / \mathrm{ml}$ (Figure 1).

GC-MS chromatogram of the BPR001 showed 6 peaks indicating the presence of 6 compounds. GC-MS analysis revealed the presence of Hexadecanoic acid, methyl ester (11.08\%), Hexadecanoic acid, ethyl ester (18.08\%), 9,12-Octadecanoic acid, (z,z)-methyl ester (21.64\%), 9-Octadecenoic acid, methyl ester, (2.95\%), Linoleic acid ethyl ester, 9,12-Octadecadienoic acid, ethyl ester. These fatty acids as major compound groups in the ethanol fractions are responsible for its actions like anti-oxidant and its antimicrobial activities.

\section{Amino acids assay}

Reddish spots appear after heating for 5 minutes; this indicated the presence of either amino acids, amines or amino sugars (Figure 2).

\section{Detection of peptides}

Purple spots showed after spraying while reddish spots appeared after heating for 20 minutes. The reddish spots were still maintained after leaving it in the oven forlhour.This indicated the presence of peptides (Figure 3).

\section{Conclusion}

The crude extract and the BPR001 showed antioxidant activity

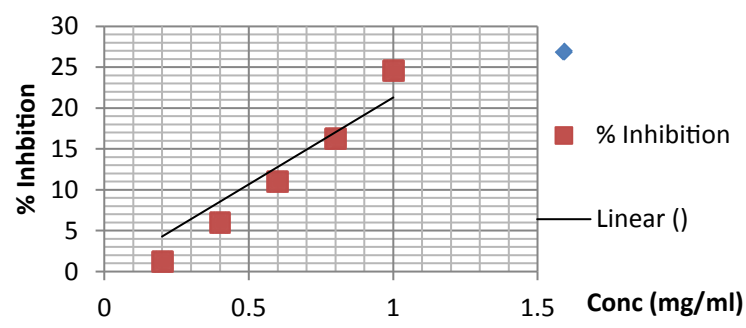

Figure 1: Antioxidant assay of BPR 001.

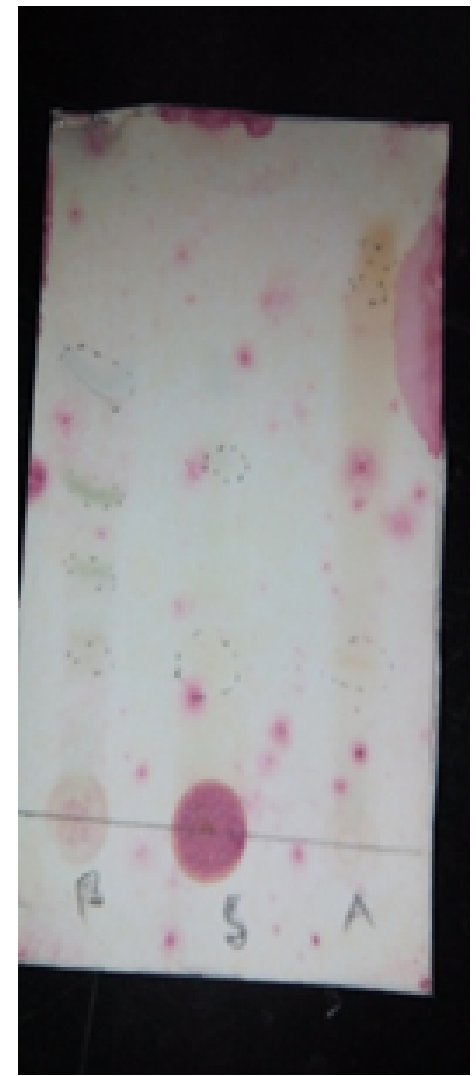

Figure 2: TLC plate of crude extract showing amino acids.

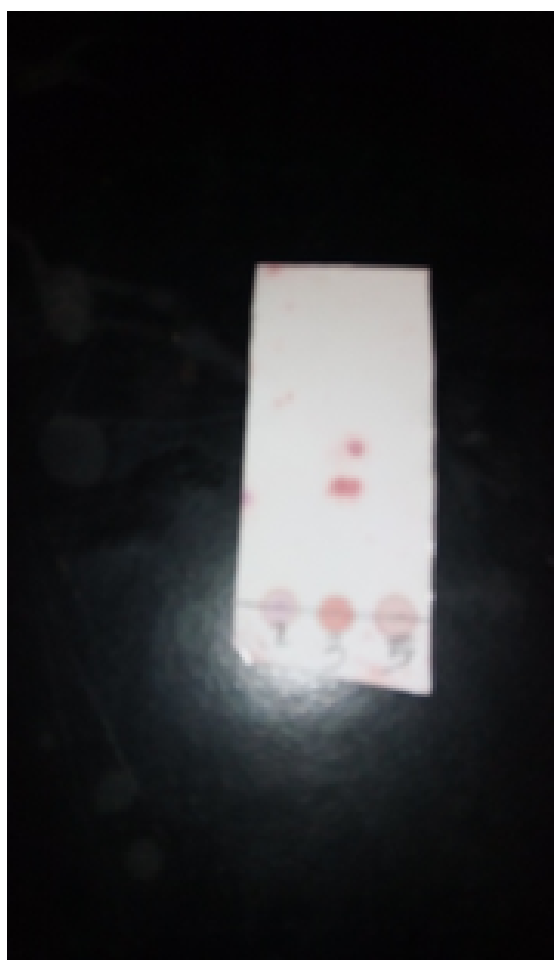

Figure 3: TLC plate of the crude extract showing peptides. 
which authenticate the medicinal folklore of the plant and is still in line with the uses of the compounds isolated from it. The compounds isolated from it serve as preservative of food in industry. Further work could still be done on it to isolate more compounds that can be useful in the industry and to isolate individual amino acids or peptides present in the root.

\section{References}

1. Nwali BU, Okaka ANC, Ibiam UA, Aja PM (2012) Phytochemical Composition of Bryphyllum Pinnatum leaves. International Journal of Advanced Biological Research 2: 614-616.

2. Umebese CE, Falana FD (2013) Growth, phytochemicals and antifungal activity of Bryophyllum pinnatum L. subjected to water deficit stress: African Journal of Biotechnology 12: 6599-6604.
3. Dassharma K, Bhatkar A, Pandey P, Shaikh N (2013) Bryophyllum pinnatum (Lam): A potential source of antioxidants. Bionano Frontier 6: 140-144.

4. Kamboj A, Saluja AK (2009) Bryophyllum pinnatum (Lam.) Kurz.: Phytochemical and pharmacological profile. A review Phcog Rev 3: 364-374.

5. Mensor LL, Menezes FS, Leitão GG, Reis AS, dos Santos TC, et al. (2001) Screening of Brazilian plant extracts for antioxidant activity by the use of DPPH free radical method. Phytother Res 15: 127-130.

6. Ruqaiyah Khan, Afzal M, Kazmi I, Chauhan M, Bisht T (2012) Chemica composition of bryophyllum. International Journal of Research in Biological Science 2: 143-149.

7. Tepe B, Daferera D, Sökmen M, Polissiou M, Sökmen A (2004) In vitro antimicrobial and antioxidant activities of the essential oils and various extracts of Thymus eigii M. Zohary et P.H. Davis. J Agric Food Chem 52: 1132-1137. 